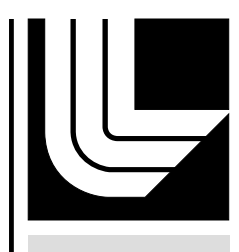

LAW RENCE LIVERMORE NATIO N A L LABORATORY

\title{
UCRL-TR-206860
}

\section{RECRYSTALLIZATION OF \\ PMDA AND SYNTHESIS OF AN ACETYLENIC DIAMINE}

R. Sanner, R. C. Cook

September 28, 2004 
This document was prepared as an account of work sponsored by an agency of the United States Government. Neither the United States Government nor the University of California nor any of their employees, makes any warranty, express or implied, or assumes any legal liability or responsibility for the accuracy, completeness, or usefulness of any information, apparatus, product, or process disclosed, or represents that its use would not infringe privately owned rights. Reference herein to any specific commercial product, process, or service by trade name, trademark, manufacturer, or otherwise, does not necessarily constitute or imply its endorsement, recommendation, or favoring by the United States Government or the University of California. The views and opinions of authors expressed herein do not necessarily state or reflect those of the United States Government or the University of California, and shall not be used for advertising or product endorsement purposes.

This work was performed under the auspices of the U.S. Department of Energy by University of California, Lawrence Livermore National Laboratory under Contract W-7405-Eng-48. 
Target Area Technologies Program

Mail Station L-481

Ext: $2-3117$

Date September 20,2004

To: Distribution

From: Robert Sanner and Bob Cook

Subject:Recrystallization of PMDA and synthesis of an acetylenic diamine.

This memo provides documentation for the method of recrystallization of pyromeletic dianhydride (PMDA), the dianhydride used in the vapor deposition of Kapton-like polyimide for ICF shell ablators and for the synthesis of bis(3-aminophenyl) acetylene, a unique acetylenic diamine developed for vapor deposition testing.

\section{RECRYSTALLIZATION OF PMDA}

\section{Day 1:}

180 g PMDA (Chriskev Corp.)

$950 \mathrm{~mL}$ glacial acetic acid

$500 \mathrm{~mL}$ acetic anhydride

Combine above reagents in a $2 \mathrm{~L} 3$-neck flask containing a 2" magnetic stirring bar. In the middle neck of the flask attach a Dean-Stark trap (wrapped with glass wool and foil to cut down on heat loss) and efficient reflux condenser. Attach a Tygon tube leading from the top of the condenser through a gas inlet/outlet tube to an oil bubbler. In another neck of the flask attach a gas inlet/outlet tube and run Tygon tubing from this connection to a nitrogen source. The final neck of the flask should be fitted with a glass stopper.

Put the flask in a $2 \mathrm{~L}$ heating mantle and place the entire apparatus on a magnetic stirring plate. If possible, stir the mixture in the flask. (This is often not possible until heating has begun and some of the PMDA has dissolved.) Begin flowing nitrogen through the system as confirmed by the action of the oil bubbler; run water through the condenser. Heat the mixture to reflux with a Variac connected to the heating mantle. As the PMDA dissolves, make sure that the solution is stirring well. Collect approx. $50 \mathrm{~mL}$ of condensate in the Dean-Stark trap, and then turn off the power to the heating mantle. As the solution cools, PMDA will begin falling out; it is essential that the mixture be well stirred during this phase of the procedure. Continue stirring the mixture overnight.

\section{Day 2:}

Decant off liquids (use glass frit if necessary) and add $100 \mathrm{~mL}$ acetic acid to the flask. Swirl the flask, then decant off (or filter if necessary) the liquid. Wash once more with $100 \mathrm{~mL}$ of acetic acid. Add $950 \mathrm{~mL}$ fresh glacial acetic acid and $500 \mathrm{~mL}$ fresh acetic anhydride and repeat the procedure of Day 1 for a second recrystallization step. 


\section{Day 3:}

Suction filter PMDA through a large $(600 \mathrm{~mL})$ glass frit: bring all PMDA onto the frit. Rinse the 3-neck flask with $100 \mathrm{~mL}$ acetic acid and bring the rinsings onto the frit to wash the PMDA. Wash the PMDA with a second $100 \mathrm{~mL}$ portion of acetic acid. Air-dry the PMDA on the frit by pulling air through the filter cake with strong suction.

Weigh out the PMDA by $10 \mathrm{~g}( \pm 0.1 \mathrm{~g})$ portions into $2 \mathrm{oz}$ wide-mouth glass jars. There should be 12-13 jars generated using this scale of recrystallization. Place the jars (uncapped) in an oven at $110^{\circ} \mathrm{C}$. Over 5-6 hours, gradually raise the temperature to 150 ${ }^{\circ} \mathrm{C}$. During this time, periodically remove the jars from the oven and break up the large clumps of PMDA with a spatula to assist drying. This should be done 2-3 times during the drying period.

Transfer jars to vacuum oven. After vacuum drying, place caps on the jars, seal with Parafilm and place in $\mathrm{N}_{2}$ dry box.

\section{SYNTHESIS OF BIS(3-AMINOPHENYL)ACETYLENE}

$36 \mathrm{~g}$ bis (tri- $n$-butylstannyl) acetylene (This was prepared as described in Macromolecules, 19, 257-266 (1986).)

$30 \mathrm{~g}$ 3-iodoaniline

$3.4 \mathrm{~g}$ tetrakis (triphenylphosphine) palladium (0)

In a $500 \mathrm{~mL}$ Schlenk flask, mix the 3-iodoaniline and tetrakis (triphenylphosphine) palladium (0) in $230 \mathrm{~mL}$ of tetrahydrofuran (previously dried by refluxing over lithium aluminum hydride). Attach an efficient reflux condenser to the top of the Schlenk flask. Put this apparatus on a vacuum system and deoxygenate by three cycles of vacuum pumping $/ \mathrm{N}_{2}$ backfill.

Mix the bis (tri- $n$-butylstannyl) acetylene with $25 \mathrm{~mL}$ tetrahydrofuran in a $100 \mathrm{~mL}$ Schlenk flask. Deoxygenate as in above procedure.

Transfer the bis (tri- $n$-butylstannyl) acetylene/THF mixture via syringe (needle fitted with Intramedic tubing) under $\mathrm{N}_{2}$ flow (to minimize oxygenation) into the iodoanilinecontaining Schlenk flask. Do this at a very fast drop wise rate of addition. After this addition is complete, deoxygenate the reaction flask two more times by the vacuum pumping $/ \mathrm{N}_{2}$ backfill procedure. Heat the reaction mixture at reflux for $66 \mathrm{hr}$.

Remove the THF at room temperature by pumping on the reaction mixture on a vacuum system containing a solvent trap. This left a dark-brown gooey substance intermixed with yellow solids. There is still a lot of liquid remaining, probably tri- $n$ butylstannyl iodide and excess iodoaniline. Remove the reaction from the vacuum system and decant off as much liquid as possible (got approx. $30 \mathrm{~mL}$ of liquid). Wash 
the solids in the flask with diethyl ether and decant off the washings. Blow off residual ether in an $\mathrm{N}_{2}$ stream.

The solids remaining in the reaction flask are dissolved in $175 \mathrm{~mL}$ chloroform. In a separatory funnel, wash this mixture twice with half-saturated potassium fluoride in water ( 2 x $100 \mathrm{~mL}$ washes); retain the lower (chloroform) layer. Next, wash the chloroform solution twice with water $(2 \times 150 \mathrm{~mL}$ washes). Finally, wash the chloroform solution twice with saturated sodium chloride in water $(2 \times 100 \mathrm{~mL}$ washes $)$. Dry the washed chloroform solution over anhydrous sodium sulfate overnight.

Filter off the sodium sulfate, and wash the solid with several small portions of chloroform. Combine all chloroform solutions and remove the solvent at room temperature on a vacuum system equipped with a solvent trap.

Scrape out the solids remaining after chloroform removal and place in a large Soxhlet extraction thimble. Put a plug of glass wool in the top of the thimble so that solids can't float out and drop the thimble into a Soxhlet extraction apparatus. Run the Soxhlet extraction overnight using $200 \mathrm{~mL}$ of diethyl ether as the extraction solvent. Filter the ether solution remaining after extraction and pump off the ether on a vacuum system at room temperature until solids begin to fall out of solution. Put the flask in a freezer overnight. Next day, collect the solids in the flask by filtration of the ether mixture and wash with small portions of ether. Air dry to obtain $10.5 \mathrm{~g}$ of yellow solid ( $85 \%$ yield). 


\section{Distribution:}

Robert D. Sanner L-092

Stephan A. Letts L-474

Steven R. Buckley L-474

Evelyn Fearon L-474

Thomas P. Bernat L-481

Bruce A Hammel L-481

Robert C. Cook L-481 